\title{
New record of \\ Dasyphyllum (Barnadesieae) from Uruguay
}

\author{
Cristina Trujillo' (D, María V.Valtierra' (iD \& Eduardo Marchesi' (1)
}

\begin{abstract}
'Laboratorio de Botánica, Facultad de Agronomía, Universidad de la República. Montevideo. Uruguay; cristgunino@gmail.com; mvvaltierra@gmail.com; ehmarch@gmail.com
\end{abstract}

DOI: http://dx.doi.org//0.53875/capitulum.01.2.06

\begin{abstract}
Dasyphyllum spinescens (Barnadesioideae) is here reported for the flora of Uruguay. This new record redefines the geographic area for Dasyphyllum (containing ca. 3l spp.) by extending its southern limit. We provide a detailed morphological description with illustrative photographs and information on the distribution, habitat, and phenology of $D$. spinescens.
\end{abstract}

Keywords: Asteraceae, Barnadesioideae, geographic distribution

\section{INTRODUCTION}

Dasyphyllum Kunth (Barnadesioideae) is exclusively distributed in South America, being recorded in the Andes from Venezuela to northwestern Argentina, and from Eastern Brazil, through Bolivia, Paraguay until northeastern Argentina (Cabrera, 1959; Stuessy et al., 2009; Urtubey, 2014; Ferreira et al., 2021). It occurs in a large number of environments ranging from dry areas such as the Puna and Cerrado to humid areas such as Atlantic forest (Cabrera, 1959; Stuessy et al., 2009; Saavedra et al., 2014, 2018; Ferreira et al., 2019, 2021). Species of Dasyphyllum generally present a shrubby habit, sometimes arboreal and lianas, the leaves have acrodromous venation, capitula are discoid with monoclinous or functionally pistillate florets (gynodioecy), corollas cream to white, and anthers show bilobed apical appendices (Stuessy et al., 2009; Ferreira et al., 2021).
Cabrera (1959) recognized 36 species of Dasyphyllum placed in two subgenera: Dasyphyllum subg. Archidasyphyllum Cabrera with two species and Dasyphyllum subg. Dasyphyllum Cabrera with 34 species. From early on, the monophyly of Dasyphyllum was questionable. The species of the subg. Archidasyphyllum had characteristics that set them apart from the rest of the Dasyphyllum species (Cabrera, 1959). Recent works that combine morphological and molecular analyzes confirm that Dasyphyllum, as it is traditionally known, is a paraphyletic group (Saavedra, 20 I I; Ferreira et al., 2019). Saavedra (20II) in her taxonomic review of the genus recognized 33 species. More recently, Ferreira et al. (2019) proposed a new circumscription of Dasyphyllum by raising the subg. Archidasyphyllum to generic rank. According to Ferreira et al. (202I), the genus includes 27 species and four species not yet described, which would render the total current 


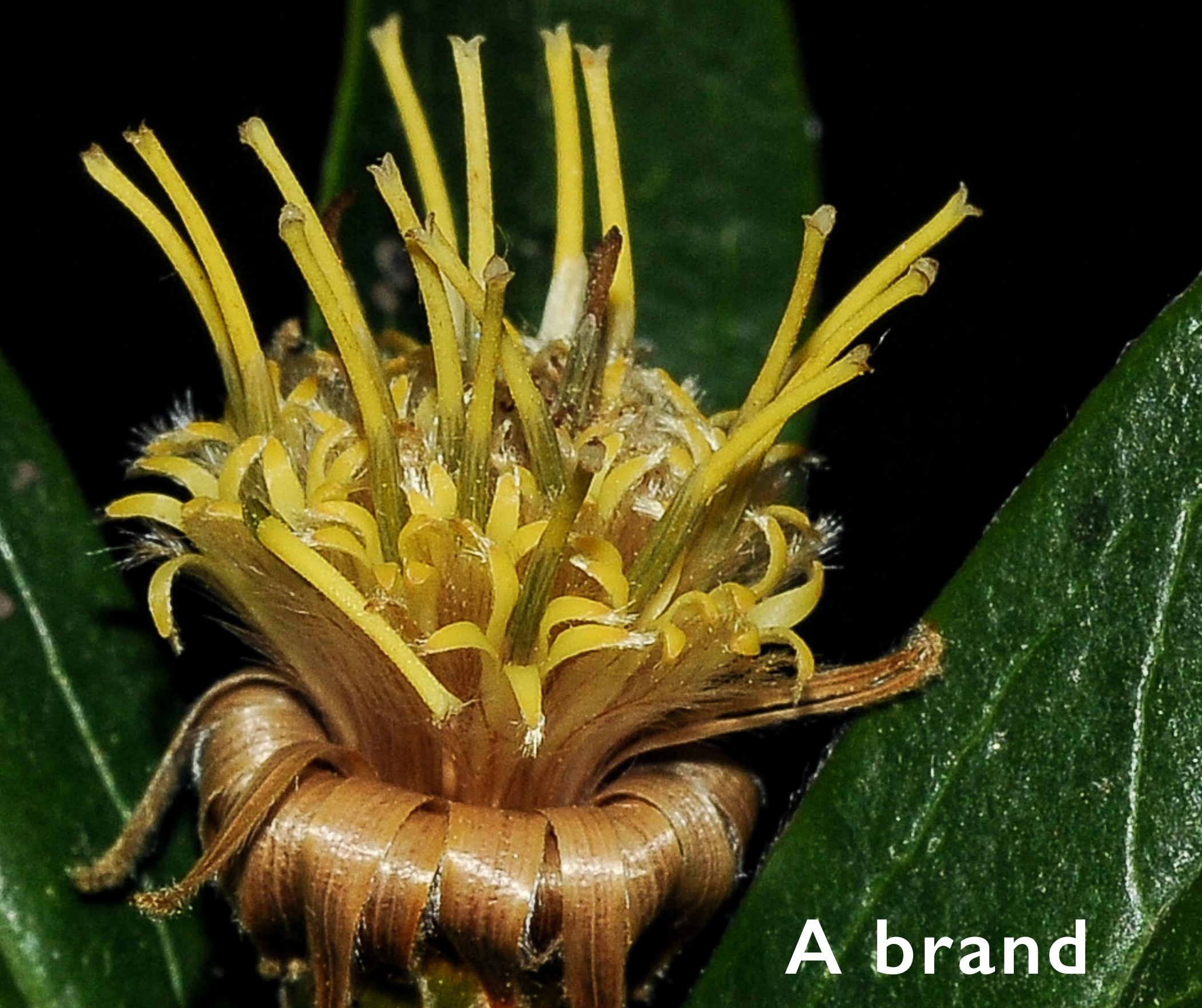



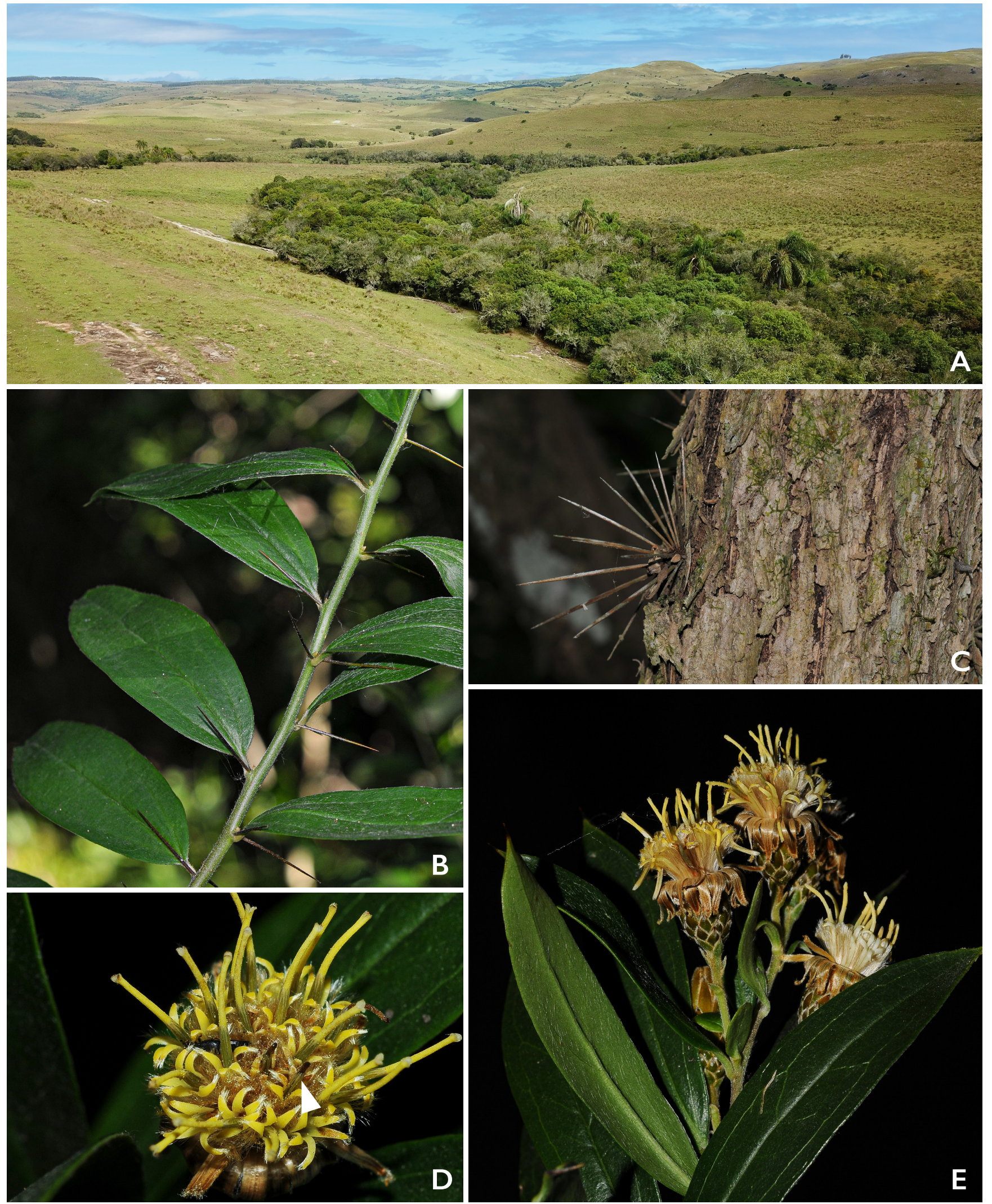

Figure I. Dasyphyllum spinescens (Less.) Cabrera. A. Habitat in Sierra de Ríos, Cerro Largo, Uruguay. B. Young branch, with spines; notice the distinctive acrodromous venetion (a generic distinctive feature). C. Rhytidome and characteristic fasciculate spines. D. Top view of the capitulum; arrow indicates bifid connectival appendage (a generic distinctive feature). E. Side view of capitulescence. Photos: M. Bonifacino. 


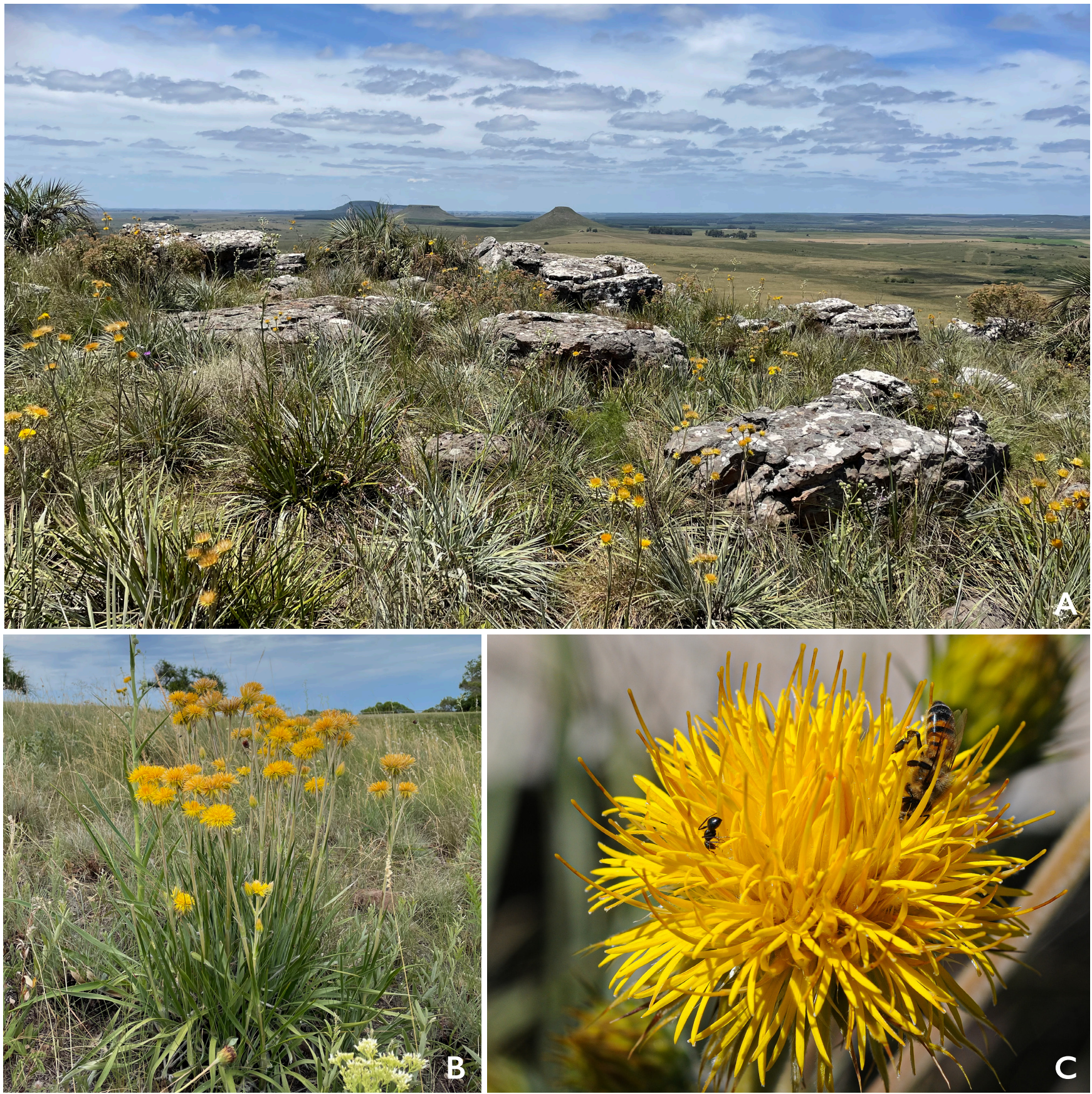

Figure 2. Schlechtendalia Iuzuliffolia Less., the other Barnadesieae species found in Uruguay. A. Habitat in Cerro Miriñaque (Rivera). B. Habit, notice grass like appearance. C. Close up of capitulum, notice pseudobilabiate corollas. Photos: M. Bonifacino.

figure to ca. 31 spp., still retaining its status as the largest genus of the tribe. The greatest diversity of the genus is in Brazil where 21 species are recognized (Stuessy et al., 2009; Saavedra, 2010).

As part of our ongoing project titled "Flora del Uruguay: Familia Compositae", we discovered Dasyphyllum (Figure I), a second genus of Barnadesieae for Uruguay. Of those two genera, monotypic Schlechtendalia Less. (Figure 2) is widely distributed across the country, while Dasyphyllum is so far restricted to one locality in northern Uruguay.

After studying collected specimens and comparing them with the information provided in the literature and the study of the type materials, we conclude that the species found in Uruguay represents the southernmost distribution of Dasyphyllum spinescens 


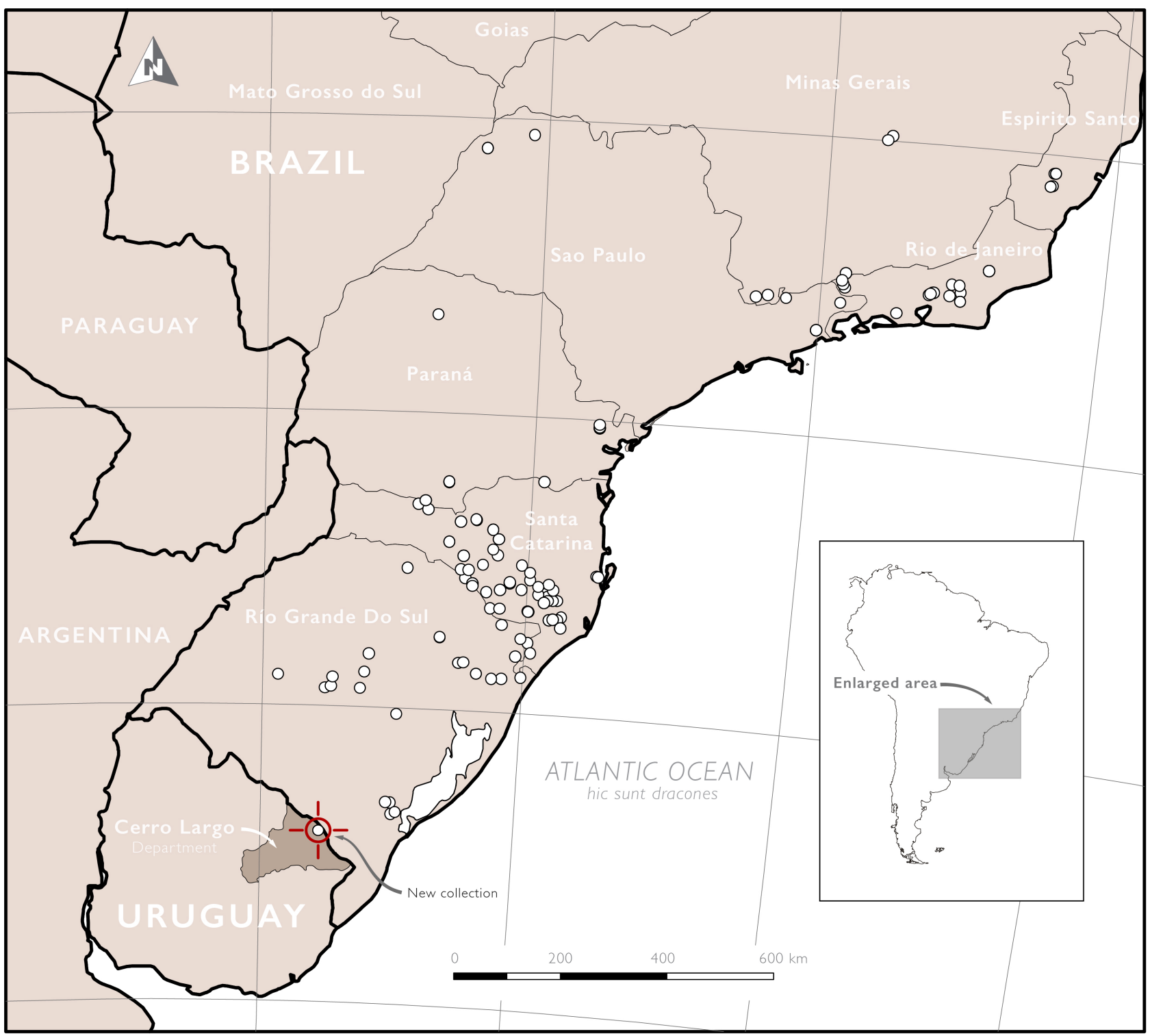

$50^{\circ} \mathrm{W}$

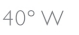

Figure 3. Dasyphyllum spinescens (Compositae: Barnadesieae) geographic distribution map.

(Less.) Cabrera, and therefore the southernmost distribution of Dasyphyllum. According to Cabrera (1959), D. spinescens is a tree characterized by light brown bark and fasciculate spines, by its upper leaves with very conspicuous spiny apex, sparsely pubescence, and capitulum with involucre campanulate.

The objective of this work is to report the presence of Dasyphyllum spinescens in Uruguay thus expanding the limits of the genus geographic distribution. We present a detailed morphological description, photographs, and a distribution map.
The images of the type specimens available on Jstor Global Plant (JSTOR, 202I) were analyzed, and the herbarium database (Reflora, 202I) was used to access the herbarium records from CEPEC, CRI, ECT, ESA, FLOR, FURB, HDCF, HEPH, HUEM, HUFU, LUSC, MBML, MG, NY, RB, RBR, US, VIES, acronyms according to Thiers (2017). For the maps, the geographical distribution was obtained from the records analyzed and plotted using QGIS version 3.4 (QGIS Development Team, 2019).

From the specimen deposited in MVFA and the fresh material collected, we made a detailed description. 
The analysis of the reproductive morphology of Dasyphyllum spinescens was carried out with both pressed material and fresh cultivated material, from a specimen of the same accession as the individual found in the wild.

\section{TAXONOMIC TREATMENT}

Dasyphyllum spinescens (Less.) Cabrera, Revista Mus. La Plata, Secc. Bot. 9 (38): 57, 1959. Flotovia spinescens Less., Linnaea 5: 251, 1830. Chuquiraga spinescens (Less.) Baker, Fl. Bras. 6 (3): 362, I 884. Type: Brazil, Brasilia, Sellow s.n. (B十) Figure I.

Trees, evergreen, ca. $6 \mathrm{~m}$ tall, stems erect, cylindrical to quadrangular, sericeous-pubescent with lenticels, adult branches with fasciculate spines. Leaves alternate, $3.5-6 \times 0.85-1.5 \mathrm{~cm}$, petioles $0.5-1 \mathrm{~cm}$ long, narrowly elliptic, base acute, apex acuminate to mucronate, adaxial and abaxial surfaces sericeous, acrodromous venation, herbaceous to coriaceous, discolor, margins entire. Capitulescences paniculiform, capitula 9 to I5, peduncles $0.8-2.5 \mathrm{~cm}$ long, sericeous-pubescent. Involucres 8-9 × 4-5 $\mathrm{mm}$, campanulate; subinvolucral bracts 0 to $4,3-6$ $\times 1.5-2 \mathrm{~mm}$, elliptic, apex acuminate to mucronate, herbaceous-coriaceous; phyllaries in 7 to 9 series, graduated in length, imbricate, dark brown, outer phyllaries 3-6 × 2-3 mm, ovate, base rounded to obtuse, apex acute, pubescent towards the margin, chartaceous, margin entire, inner phyllaries 6-7 $\times$ 2-2.3 mm, ovate, curved outwards, base acute to obtuse, apex acute, pubescent to puberulous on abaxial surface, puberulous at the apex on adaxial surface, chartaceous, margin entire. Receptacles flat, paleate, pilose. Paleae ca. |4, |0.5-II × $0.5 \mathrm{~mm}$, linear in the first two-thirds and elliptic towards the apex, base acute, apex acute, pubescent on abaxial surface and glabrous on adaxial surface, chartaceous, margins entire. Florets ca. 25, monoclinous, in 2 to 3 series, corollas tubulose, tube 4-4.2 mm long, lobes $5,4-5 \times 0.5-0.6 \mathrm{~mm}$, elliptic, corollas light yellow to white-yellow, tube villous inside, lobes villous to tomentose towards the apex on abaxial surface and glabrous adaxially. Anthers slightly sagittate 4.2-4.3 $\mathrm{mm}$ long, basal appendages $0.3 \mathrm{~mm}$ long, connective appendix $0.3 \times 0.3 \mathrm{~mm}$, bilobed, lobes ovates, apex acute. Style $12 \mathrm{~mm}$ long, style branches $0.5 \mathrm{~mm}$ long, ovate, apex acute, glabrous. Cypselae 2.1-2.5 mm long, fusiform cylindrical, tomentose. Pappus 7-8.5 $\mathrm{mm}$ long, uniseriate, homomorphic, stramineous plumose bristles, persistent.

Distribution and habitat: Southeastern and southern Brazil, in the states of Minas Gerais, Espírito Santo, São Paulo, Rio de Janeiro, Paraná, Santa Catarina and Rio Grande do Sul (Cabrera, 1959; Saavedra, 2010). Dasyphyllum spinescens has only been reported for Uruguay in the department of Cerro Largo (Figure 3), where it grows in subtropical semideciduous submontane riverine forests (Figure |A).

Phenology: Flowering from February to March.

Specimens examined: URUGUAY.CERRO LARGO: Sierra de Ríos, Cuchilla de Yaguarón, S 3207'40.2 I" W 5349'49.67", | 3-III-20I2, Bonifacino \& Speroni 4273 (MVFA).

\section{ACKNOWLEDGMENTS}

This work is part of the results of the ongoing Flora of Uruguay Project. We would like to thank Facultad de Agronomía, Facultad de Ciencias (UdelaR) and Agencia Nacional de Investigación e Innovación (ANII) through project FCEI04963 and PEDECIBA (Facultad de Ciencias, UdelaR) for their financial support. We also thank Ph.D. Mariana Saavedra for her help in sharing useful bibliographic material. Finally, we also thank the anonymous reviewers whose comments and suggestions greatly improved the manuscript.

\section{LITERATURE CITED}

Cabrera, A.L. 1959. Revisión del género Dasyphllum (Compositae). Rev. Mus. La Plata, Nueva serie, Secc. Bot. 9 (38): $21-100$.

Ferreira, P.dL., Saavedra, M.M. \& Groppo, M. 2019. Phylogeny and circumscription of Dasyphyllum (Asteraceae: Barnadesioideae) based on molecular data with the recognition of a new genus, Archidasyphyllum. Peerf 7:e6475. DOI I0.77। 7 / peerj.6475.

Ferreira, P.dL., Antonelli, A. \& Groppo, M. 2021. Touch me carefully: a step towards understanding morphological diversity in the South American spiny sunflowers (Compositae, Barnadesioideae). Phytotaxa 5 I8 (2): I09-|42. DOI I 0.1 I 646/ phytotaxa.5 | 8.2.3. 
JSTOR. 202 I. Global Plants [Continuously updated] ITHAKA. All Rights Reserved. Available from: https://plants.jstor.org (last access: October 29, 202I).

QGIS Development Team. 2019. QGIS Geographic Information System, version 3.4. Open Source Geospatial Foundation Project. Available from: http://qgis.osgeo.org (last access: October 29, 2021).

Reflora. 2021. Virtual Herbarium [Continuously updated]. Available from: http://reflora.jbrj.gov.br/reflora/herbarioVirtual/ ConsultaPublicoHVUC/ConsultaPublicoHVUC. do;jsessionid=http://reflora.jbrj.gov.br/reflora/herbarioVirtual/ ConsultaPublicoHVUC/ConsultaPublicoHVUC. do;jsessionid=http://reflora.jbrj.gov.br/reflora/herbarioVirtual/ (last access: October 29, 2021).

Saavedra, M.M. 20I0. Dasyphyllum Kunth. In: Forzza, R.C., Baumgratz J.F.A., Bicudo C.E.M., Carvalho Jr.A.A., Costa A., Costa D.P., Hopkins M., Leitman P.M., Lohmann L.G., Maia L.C., Martinelli G., Menezes M., Morim M.P., Coelho M.A.N., Peixoto A.L., Pirani J.R., Prado J., Queiroz L.P., Souza V.C., Stehmann J.R., Sylvestre L.S., Walter B.M.T. \& Zappi D. (eds). Catálogo de Plantas e Fungos do Brasil. Vol. I. Rio de Janeiro : Andrea Jakobsson Estúdio: Instituto de Pesquisas Jardim Botânico do Rio de Janeiro, Brasil.

Saavedra, M.M. 2011. Sistemática de Dasyphyllum (Asteraceae). PhdThesis. Instituto de Pesquisas Jardim Botânico do Rio de Janeiro, Rio de Janeiro, pp. I-247.
Saavedra, M.M., Monge, M. \& Guimarães, E.F. $20 \mid 4$. Dasyphyllum diamantinense (Asteraceae, Barnadesioideae): A new species from the Chapada Diamantina, Bahia State, Brazil. Phytotaxa I74 (4): 23 I-236. DOI I 0.I I 646/phytotaxa. I 74.4.4.

Saavedra, M.M., Guimarães, E.F., Loeuille, B. \& Forzza, R.C. 2018. Taxonomic Revision of Dasyphyllum sect. Macrocephala (Asteraceae: Barnadesioideae). Syst. Bot. 43: 297-315. DOI 10.1600/0363644|8X696888.

Stuessy, T.F., Urtubey, E. \& GruenstaeudI, M. 2009. Barnadesieae (Barnadesioideae) Pp. 215-228, in: Funk, V.A., A. Susanna, T.F. Stuessy, y R.J. Bayer (eds.). Systematics, Evolution, and Biogeography of Compositae.Vienna, Austria.

Thiers, B. 20 17. Index Herbariorum: A global directory of public herbaria and associated staff. New York Botanical Garden's Virtual Herbarium. Available from: http://sweetgum.nybg.org/ ih/ (last access: October 29, 2021).

Urtubey, E. 2014. Dasyphyllum Kunth. Pp. 260-264 in:Zuloaga, F.O., Belgrano, M.J. \& Anton, A.M. (eds.). Asteraceae:Anthemideae A Gnaphalieae. Flora Argentina. Flora Vascular de la República Argentina. Estudio Sigma S.R.L., Bs As. 7 (I). 